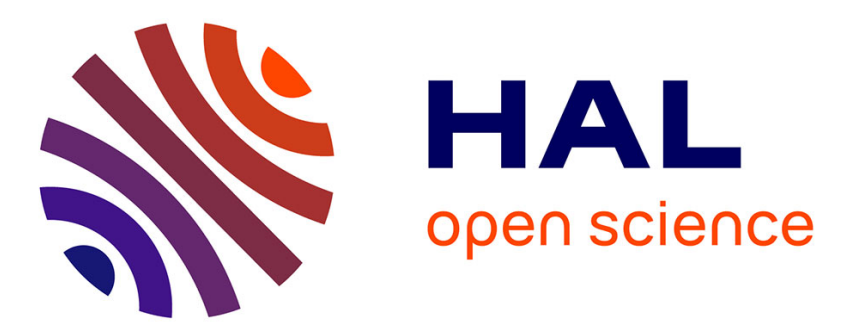

\title{
Responses of the marine bacterium Pseudomonas fluorescens to an excess of heavy metals: Physiological and biochemical aspects
}

\author{
Isabelle Poirier, Natacha Jean, J.C. Guary, M. Bertrand
}

\section{- To cite this version:}

Isabelle Poirier, Natacha Jean, J.C. Guary, M. Bertrand. Responses of the marine bacterium Pseudomonas fluorescens to an excess of heavy metals: Physiological and biochemical aspects. Science of the Total Environment, 2008, 406 (1-2), pp.76-87. 10.1016/j.scitotenv.2008.07.038 . hal-03244216

\author{
HAL Id: hal-03244216 \\ https://hal.science/hal-03244216
}

Submitted on 1 Jun 2021

HAL is a multi-disciplinary open access archive for the deposit and dissemination of scientific research documents, whether they are published or not. The documents may come from teaching and research institutions in France or abroad, or from public or private research centers.
L'archive ouverte pluridisciplinaire HAL, est destinée au dépôt et à la diffusion de documents scientifiques de niveau recherche, publiés ou non, émanant des établissements d'enseignement et de recherche français ou étrangers, des laboratoires publics ou privés. 


\title{
Responses of the marine bacterium Pseudomonas fluorescens to an excess of heavy metals: Physiological and biochemical aspects
}

\author{
I. Poirier ${ }^{a, *, 1}$, N. Jean ${ }^{b, 1}$, J.C. Guary $^{a}$, M. Bertrand ${ }^{a}$ \\ a Equipe Microorganismes-Métaux-Toxicité, Laboratoire d’Etudes et de Recherches Marines, Institut National des Sciences et Techniques de la \\ Mer, Conservatoire National des Arts et Métiers, BP 324, F-50103 Cherbourg Cedex, France \\ ${ }^{\mathrm{b}}$ Equipe d'Ecologie et de Biologie des Milieux Aquatiques, Laboratoire des Processus de Transfert et des Echanges en Environnement (EA 3819), \\ Université du Sud Toulon-Var, BP 20132, F-83957 La Garde Cedex, France
}

Keywords:

Pseudomonas fluorescens

Metal stress

Growth

Respiration

Alkaline phosphatase

Proteomics

\section{A B S T R A C T}

A Pseudomonas fluorescens strain was isolated from oxic marine sediments obtained from the strand zone of the St Anne Bay (a moderately metal-contaminated site to the west of Cherbourg harbour). The strain, which exhibited a high tolerance to metal contamination when cultivated (minimal inhibitory concentration $=950 \mu \mathrm{M}\left[62 \mathrm{mg} \mathrm{L}^{-1}\right]$ for $\mathrm{Zn}, 660 \mu \mathrm{M}\left[42 \mathrm{mg} \mathrm{L}^{-1}\right]$ for Cu, and $505 \mu \mathrm{M}\left[57 \mathrm{mg} \mathrm{L}^{-1}\right]$ for $\mathrm{Cd}$ ), was further characterized by its physiological and biochemical responses to metal additions to the culture medium. Bacterial growth was significantly disturbed

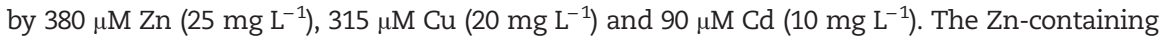
alkaline phosphatase was studied as an intoxication biomarker. Its activity was stimulated (+9\%) by an excess of $\mathrm{Zn}$, but inhibited by $\mathrm{Cd}(-55 \%)$ and $\mathrm{Cu}(-10 \%)$, these two elements could displace the native $\mathrm{Zn}$ or/and disturb the enzyme $3 \mathrm{D}$-structure. Bacterial $\mathrm{O}_{2}$ consumption was recorded as a global physiological response to metal stress. This parameter dropped with increasing $\mathrm{Cd}$ and $\mathrm{Cu}$ contamination $\left(-49 \%\right.$ and $-45 \%$, respectively, at $\left.20 \mathrm{mg} \mathrm{L}{ }^{-1}\right)$. By contrast, $\mathrm{Zn}$ increased $\mathrm{O}_{2}$ consumption (approximately $+40 \%$ for the different tested concentrations). The proteomes of bacteria grown in the presence or absence of $20 \mathrm{mg}$ metal $\mathrm{L}^{-1}$ were characterized by 2D-gel electrophoresis. The number of spots exhibiting a difference in intensity between the contaminated sample and the control was 65,68 , and 103, for $\mathrm{Zn}$, Cu and $\mathrm{Cd}$, respectively. Among them, 45, 61 and 82 spots respectively appeared de novo or increased in intensity, indicative of metal-stimulated synthesis, particularly for Cu and Cd. In summary, whereas $\mathrm{Cd}$ and $\mathrm{Cu}$ treatments both stressed cells and slowed down primary metabolism to differing extents, $\mathrm{Zn}$ has a stimulating action on several physiological and biochemical parameters.

\section{Introduction}

Pseudomonas fluorescens is found in various environments. It is well described in cultivated soils (Silby and Levy, 2004;
Siddiqui et al., 2005) and in sewage sludge (Ciesielski et al., 2006; Takenaka et al., 2007). Many studies indicate its presence in the marine environment, (Newman and Cragg, 2004; CastroGonzález et al., 2005), but only a few describe strains from the

Abbreviations: AP, alkaline phosphatase; APA, alkaline phosphatase activity; IEF, isoelectric focusing; MIC, minimal inhibitory concentration; pNPP, paranitrophenyl phosphate; pNP, paranitrophenol.

* Corresponding author. Tel.: +332 338873 34; fax: +33233887339.

E-mail address: isabelle.poirier@cnam.fr (I. Poirier).

${ }^{1}$ Equal contribution of both authors. 
oxic layer of the strand zone. This zone is very particular in the sense that it is submitted to variations of several parameters such as salinity, temperature, water turbulence, and light. Moreover, during the last decades, increased human activities have resulted in an accumulation of heavy metals, which particularly affect the coastal zone by accumulating in sediments (Zhou et al., 2007a,b). Consequently, the bacteria which live in this specific environment must adapt to numerous stresses (Azam and Malfatti, 2007). P. fluorescens species is known for its stress resistance (Stockwell and Loper, 2005). In the marine environment, its capacities of adaptation has been described especially against pollutants like hydrocarbons (Bamforth and Singleton, 2005; Vasudevan et al., 2007) but nothing is known about the metal resistance capacity of strains isolated from the strand zone.

This study reports the characterization of a P. fluorescens strain (strain BA3d12) isolated from the strand zone of St Anne Bay at the west of Cherbourg seaport. Previous studies carried out in this bay have reported a metal contamination of the sediments, probably due to seaport activities, urban effluents and industrial wastes which flow into this local marine area (confidential data). We report the ability of this strain to respond to an excess of metals through physiological and biochemical measurements. The metals tested were zinc, copper and cadmium, these elements being currently found in contaminated sites. Zinc and copper are essential elements, required for normal growth, development and survival of all living systems, whereas cadmium is generally toxic because it has no known biological role (Ron et al., 1992). Among the physiological responses tested, we have focussed on the minimal inhibitory concentration (MIC), growth, rate of $\mathrm{O}_{2}$ uptake and alkaline phosphatase activity (APA). The respiration rate is generally considered to be a reliable index of microorganism metabolic processes, and toxicity of metals can be evaluated by modification of respiratory activity (King and Painter, 1986). Alkaline phosphatase (EC 1.3.1.3) was selected as it represents an intoxication biomarker in ecotoxicological studies, due to its high sensitivity to metal salts (Boge et al., 1988). By precipitating metal ions with phosphates, this enzyme is moreover involved in mechanisms of detoxification (Macaskie et al., 1992). When organisms are submitted to a metal ion stress, particular metabolic pathways generally arise (Silver 2003; Mergeay et al., 2003) involving stress proteins. Currently, the only publication that presents proteomics of metallic-stressed P. fluorescens (Sharma et al., 2006) does not concern bacteria isolated from a marine environment. Therefore, we have decided to study the proteome response to metal stress in the marine strain BA3d12 by comparing the proteomes of non-contaminated and contaminated cells using two-dimensional gel electrophoresis.

\section{Materials and methods}

\subsection{Bacterial strain isolation and growth conditions}

P. fluorescens (strain BA3d12) was isolated from the top 2-cm layer of oxic marine sediments collected on the seashore, at low tide in the St Anne Bay (west of Cherbourg harbour: $49^{\circ} 39$ $\mathrm{N}-01^{\circ} 40 \mathrm{~W}$, France). Long-term storage was at $-80{ }^{\circ} \mathrm{C}$ in $25 \%$ glycerol. During the experimental period, the strain was stored at $+4{ }^{\circ} \mathrm{C}$ on CFC agar plates and maintained by monthly subcultures. For all experiments, P. fluorescens BA3d12 was cultivated at $+22{ }^{\circ} \mathrm{C}$ in $100 \mathrm{~mL}$ of nutrient broth containing $1 \%(\mathrm{w} / \mathrm{v})$ tryptone, $0.5 \%(\mathrm{w} / \mathrm{v})$ meat extract, $0.5 \%(\mathrm{w} / \mathrm{v}) \mathrm{NaCl}$ (Biokar Diagnostics, Beauvais, France). Cultures were inoculated with $1 \mathrm{~mL}$ of bacterial suspension from a $24 \mathrm{~h}$-old preculture.

To study growth kinetics, $\mathrm{O}_{2}$ consumptions and proteomes, the nutrient broth was supplemented with different $\mathrm{Zn}$, Cu or Cd concentrations ( 0 to $25 \mathrm{mg} \mathrm{L}^{-1}$ ) using $1 \mathrm{~g} \mathrm{~L}^{-1} \mathrm{ZnCl}_{2}, \mathrm{CuCl}_{2}$, and $\mathrm{CdCl}_{2}$ stock solutions. For measurements of alkaline phosphatase activity, $\mathrm{O}_{2}$ consumption measurements and 2Delectrophoresis, cultures were harvested at the end of the exponential growth phase, so that the bacterial concentration was always $2.10^{8}$ cells $\mathrm{mL}^{-1}$, which corresponds to 0.330 absorbance unit at $600 \mathrm{~nm}$ (Spectronic 20 Genesis, Rochester, NY, USA).

\subsection{Minimal Inhibitory Concentration (MIC) determination}

MICs of the isolated strain BA3d12 were determined in the media described above, supplemented with increasing concentrations (up to $80 \mathrm{mg} \mathrm{L}^{-1}$ ) of a given metal. The cultures were incubated for up to 15 days, and growth was monitored by absorbance measurements at $600 \mathrm{~nm}$. MIC is generally defined as the lowest metal concentration for which the growth is inhibited.

\subsection{Growth kinetics}

Growth kinetics of contaminated and control BA3d12 cultures were monitored until stationary phase, by cell counting with a Thoma cell.

\subsection{Alkaline phosphatase activities}

Each cell culture was first concentrated by centrifugation at $10000 \mathrm{~g}$ for $10 \mathrm{~min}$ at $+22^{\circ} \mathrm{C}$. The pellet was then resuspended in $20 \mathrm{~mL}$ of a buffer $\mathrm{pH} 10.5$, containing $0.1 \mathrm{M}$ glycine, $0.5 \mathrm{mM}$ $\mathrm{MgCl}_{2} 6 \mathrm{H}_{2} \mathrm{O}, 85 \mathrm{mM} \mathrm{NaOH}$. In order to efficiently extract the phosphatase from the cells, two cell disruption methods have been compared: high pressures delivered by a French Press and ultrasonication using a microtip. The highest APA was consistently found in the French Press extract; as a result, for all APA measurements, the concentrated cell sample was submitted to one passage at $159 \mathrm{MPa}$ through a pre-cooled French Press (French Pressure Cell 40 K, Thermo IEC, Needham Heights, MA, USA). The protein concentration in the enzyme extract was determined according to the Bradford method (Bradford, 1976). All protein measurements were carried out in duplicates. The enzyme extract was immediately exposed to increasing concentrations of substrate (paranitrophenylphosphate $=$ pNPP), contaminated with different concentrations of a given metal. For comparison, a control reaction was performed by incubation of the enzyme with the noncontaminated pNPP. All these reactions were carried out in the $300 \mu \mathrm{L}$-wells of a microtitre plate, with a ratio of $100 \mu \mathrm{L}$ enzyme to $200 \mu \mathrm{L}$ substrate. The resulting product paranitrophenol (pNP) concentrations were followed by absorbance 
measurements at $405 \mathrm{~nm}$ using a microplate reader Apollo-1 (Berthold Technologies GmbG \& Co. KG, Bad Wildbad, Germany). Data acquisition was performed with the MikroWin 20004.0 version software (Mikrotek Laborsysteme $\mathrm{GmbH}$, Overath, Germany). Under these conditions, APA was measured at $+22^{\circ} \mathrm{C}$ for $4 \mathrm{~h}$, at 10 minute intervals. The MichaelisMenten constants, $\mathrm{V}_{\max }$ (reaction rate when the enzyme is saturated with substrate) and $\mathrm{K}_{\mathrm{m}}$ (half saturation concentration), were calculated with the CurveExpert 1.3 version software (curve fitting system for Windows) as described in Jean et al. (2003).

\section{5. $\mathrm{O}_{2}$ consumption rates}

The $\mathrm{O}_{2}$ consumption rate of the bacterial cell cultures was measured with a Clark-type electrode maintained at $+22{ }^{\circ} \mathrm{C}$ with a polystat (Eurosep Instruments, Cergy St Christophe, France). The electrode was first calibrated in air-saturated water $\left(100 \% \mathrm{O}_{2}\right)$ and then with a sodium sulfite solution $\left(0 \% \mathrm{O}_{2}\right)$. The cell suspensions were constantly stirred (speed $50 \mathrm{rpm})$, to promote oxygen diffusion through the PTFE membrane. Molecular oxygen was electrolytically reduced by a platinum cathode maintained at $1.5 \mathrm{~V}$. The cathode was then depolarized, allowing a current to flow, proportional to the oxygen activity (Clark, 1956). Data was acquired using the Oxylab 1.07 version software (Hansatech Instruments, Norfolk, England), which provides the $\mathrm{O}_{2}$ concentration decrease versus time allowing calculation of the $\mathrm{O}_{2}$ consumption rate. The results of the first tests carried out in our laboratory indicated that addition of the metal contamination directly to the measurement chamber led to electrode deterioration. For this reason, it was not possible to record the instantaneous effect of an excess of metal on the respiration rate. Therefore, we followed the sample preparation protocol of Navarro et al. (1997), in which the metal was added to the culture broth before bacterial inoculation. The bacteria were cultivated in this contaminated broth until the end of the exponential growth phase. The contaminated cell culture was then centrifuged at $10000 \mathrm{~g}$ for $10 \mathrm{~min}$ at $+22{ }^{\circ} \mathrm{C}$. The pellet was washed in $12 \mathrm{~mL}$ of $0.1 \mathrm{M} \mathrm{K}_{2} \mathrm{HPO}_{4}$ buffer $\mathrm{pH}$ 7.5. After removal of the supernatant, the pellet was resuspended in $12 \mathrm{~mL}$ of the buffer and distributed into three $4 \mathrm{~mL}$ aliquots. These suspensions were centrifuged at $10000 \mathrm{~g}$ for $10 \mathrm{~min}$ at $+22^{\circ} \mathrm{C}$. Finally, each pellet was vortexed in $2 \mathrm{~mL}$ of nutrient broth just before analysis using the Clark-type electrode. The three replicates were compared to a control, processed under the same conditions.

\subsection{D-PAGE analysis of soluble proteins}

\subsubsection{Preparation of protein extracts}

Contaminated $\left(20 \mathrm{mg} \mathrm{L}^{-1}\right)$ and control cultures were centrifuged at $10000 \mathrm{~g}$ for $10 \mathrm{~min}$ at $+22^{\circ} \mathrm{C}$. The pellets were washed twice and resuspended in $10 \mathrm{~mL}$ of ultrapure water. Cells were disrupted by three passages at $159 \mathrm{MPa}$ through the pre-cooled French Press. The resulting homogenate was centrifuged for $10 \mathrm{~min}$ at $10000 \mathrm{~g}$ at $+4{ }^{\circ} \mathrm{C}$ to pellet down cell debris. Protein concentration in the supernatant was determined according to Bradford (1976). All protein extracts were purified and concentrated five times with a centrifugal concentrator (Amicon
Ultra-4 Millipore, $10 \mathrm{kDa}$ cut-off size, Bedford, MA, USA) and stored at $-80^{\circ} \mathrm{C}$ until analysis.

\subsubsection{D-electrophoresis}

For isoelectric focusing (IEF), $200 \mu \mathrm{g}$ of protein was dissolved in a rehydration buffer containing $8 \mathrm{M}$ urea, $4 \%(\mathrm{w} / \mathrm{v})$ CHAPS, $20 \mathrm{mM}$ DTT, 0.2\% Bio-Lyte 3-10 and 0.001\% (w/v) bromophenol blue. After active rehydration at $50 \mathrm{~V}$ for $17 \mathrm{~h}$ under paraffin oil, $17 \mathrm{~cm}$-long immobilized pH gradient (IPG) strips ( $\mathrm{pH}$ 3-10, BioRad) were submitted to IEF (Protean IEF Cell, Bio-Rad) with the following voltage/time process: $150 \mathrm{~V}$ for $1 \mathrm{~h}$ with rapid ramping, $350 \mathrm{~V}$ for $15 \mathrm{~min}$ with rapid ramping, $750 \mathrm{~V}$ for $45 \mathrm{~min}$ with rapid ramping, $1500 \mathrm{~V}$ for $1 \mathrm{~h}$ with rapid ramping and $3500 \mathrm{~V}$ for $18 \mathrm{~h}$ with rapid ramping (adapted from Vilain et al., 2004). After IEF separation, strips were consecutively incubated in equilibration buffers $A$ and B for $15 \mathrm{~min}$ [50 mM Tris/HCl, pH 8.8, $6 \mathrm{M}$ urea, 30\% (v/v) glycerol, $2 \%$ (w/v) SDS, with $65 \mathrm{mM}$ DTT (solution A) or $135 \mathrm{mM}$ iodoacetamide (solution B)]. In the second dimension, proteins were separated by SDSPAGE on $17 \times 17 \mathrm{~cm}$ gels containing $12.5 \%$ acrylamide according to Laemmli (1970). The gels were run in a Protean II cell (BioRad) at $+4{ }^{\circ} \mathrm{C}(1 \mathrm{~h}$ at $25 \mathrm{~V}$, then at $200 \mathrm{~V}$ until the bromophenol blue dye reached $5 \mathrm{~mm}$ from the bottom of the gel). Proteins were visualized by gel staining with the Dodeca silver stain kit (Bio-Rad). The stained gels were analysed using the PD-Quest software 7.3.0 version (Bio-Rad).

\section{Results}

\subsection{MICs}

The MIC values for the three heavy metals tested are $950 \mu \mathrm{M}$ (62 $\left.\mathrm{mg} \mathrm{L}^{-1}\right)$ for $\mathrm{Zn}, 660 \mu \mathrm{M}\left(42 \mathrm{mg} \mathrm{L}^{-1}\right)$ for Cu and $505 \mu \mathrm{M}\left(57 \mathrm{mg} \mathrm{L}^{-1}\right)$ for $\mathrm{Cd}$. These results show that the order of BA3d12 strain's metal sensitivity was $\mathrm{Cd}>\mathrm{Cu}>\mathrm{Zn}$.

\subsection{Pseudomonas BA3d12 growth kinetics}

\subsubsection{Zinc}

BA3d12 growth in the presence of increasing $\mathrm{Zn}$ concentrations is presented in Fig. 1A. For zinc concentrations of $0,5,10$, and $20 \mathrm{mg} \mathrm{L}^{-1}$, no significant difference was observed in growth kinetics (Wilcoxon test: $p>0.01$ ). However, the lag phase for contaminated cultures is slightly longer $(4 \mathrm{~h}$ instead of $2 \mathrm{~h}$ ). For $25 \mathrm{mg} \mathrm{L}^{-1} \mathrm{Zn}(380 \mu \mathrm{M})$, significant differences occurred in comparison to the control (Wilcoxon test: $p<0.01$ ). The lag phase was considerably increased (32 h) and the maximum growth rate was slightly lower than the control $\left(0.42 \mathrm{~h}^{-1}\right.$ instead of $\left.0.60 \mathrm{~h}^{-1}\right)$. Therefore, this strain was highly tolerant to $\mathrm{Zn}$, its growth being significantly affected only by high $\mathrm{Zn}$ concentrations (>20 $\mathrm{mg} \mathrm{L}^{-1}$ or $305 \mu \mathrm{M}$ ).

For the control and all the $\mathrm{Zn}$ concentrations tested, the same cell concentration was observed in the stationary phase.

\subsubsection{Copper}

The results of the evolution of BA3d12 cell concentration in the presence of increasing copper concentrations are shown in Fig. 1B. For $5 \mathrm{mg} \mathrm{L}^{-1} \mathrm{Cu}$, there was no significant change, in either the acclimation phase or the exponential 


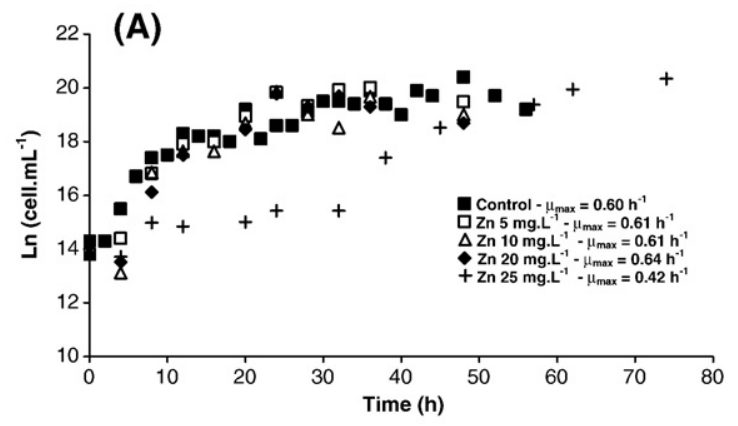

(B)

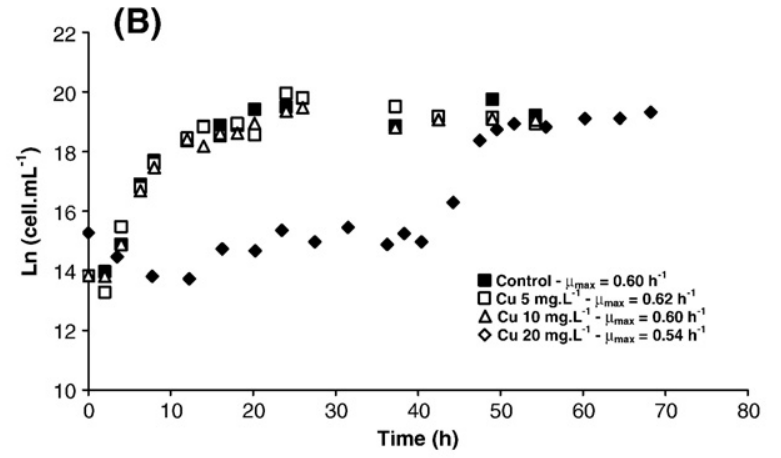

(C)

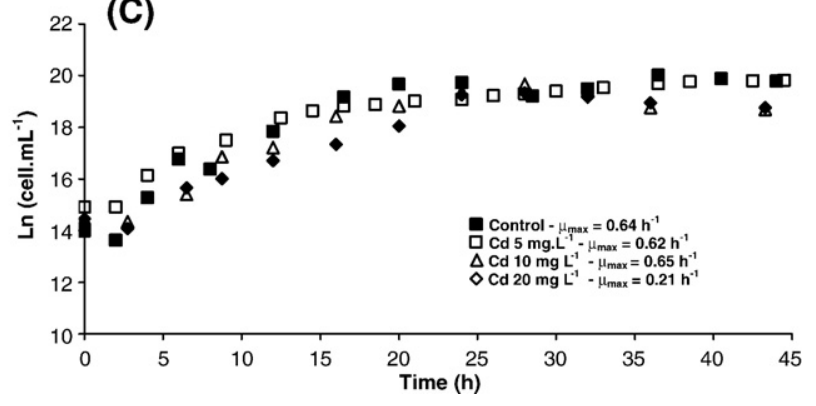

Fig. 1-Growth of Pseudomonas fluorescens BA3d12 in the presence of different concentrations of $\mathrm{Zn}(\mathrm{A}), \mathrm{Cu}(\mathrm{B})$ and $\mathrm{Cd}(\mathrm{C})$.

phase, compared to the control (Wilcoxon test: $p>0.01$ ). For $10 \mathrm{mg} \mathrm{L}^{-1} \mathrm{Cu}$, the Wilcoxon test indicated that growth kinetics differed $(p<0.01)$, between the control and the contaminated cultures. As indicated by the Wilcoxon test, it is obvious that both kinetics were similar, since no significant difference existed between 5 and $10 \mathrm{mg} \mathrm{L}^{-1} \mathrm{Cu}(p>0.01)$. For the highest $\mathrm{Cu}$ concentration $\left(20 \mathrm{mg} \mathrm{L}^{-1}\right.$ or $\left.315 \mu \mathrm{M}\right)$, growth kinetics were distinct from that of the control (Wilcoxon test: $p<0.01$ ). A very long lag phase of $42 \mathrm{~h}$ was observed, as well as a slight decrease in the maximum growth rate $\left(0.54 \mathrm{~h}^{-1}\right.$ instead of $\left.0.60 \mathrm{~h}^{-1}\right)$. For all the $\mathrm{Cu}$ concentrations tested, the cell concentrations at the stationary phase were similar to those of the control.

\subsubsection{Cadmium}

The growth kinetics of BA3d12 in the presence of increasing $\mathrm{Cd}$ concentrations is presented in Fig. 1C. At $5 \mathrm{mg} \mathrm{L}^{-1}$, there was no significant change neither in the acclimation phase, nor in the exponential phase, compared to the control (Wilcoxon test: $p>0.01)$. However, statistical differences were revealed by the Wilcoxon test $(p<0.01)$ between $10 \mathrm{mg} \mathrm{L}^{-1} \mathrm{Cd}(90 \mu \mathrm{M})$ and the control. These differences were probably due to the earlier decline in growth observed for the contaminated culture from $35 \mathrm{~h}$ onwards. Indeed, if this decline phase is not taken into account, the statistical test revealed no difference $(p>0.01)$, the lag phase increasing slightly ( $4 \mathrm{~h}$ instead of $2 \mathrm{~h}$ ), and the maximum growth rates being comparable between the control and the contaminated cultures (respectively $0.65 \mathrm{~h}^{-1}$ and $\left.0.64 \mathrm{~h}^{-1}\right)$. For the highest $\mathrm{Cd}$ concentration $\left(20 \mathrm{mg} \mathrm{L}^{-1}\right.$ or $180 \mu \mathrm{M})$, a lag phase of $4 \mathrm{~h}$, a major decrease in the maximum growth rate $\left(0.21 \mathrm{~h}^{-1}\right.$ instead of $\left.0.64 \mathrm{~h}^{-1}\right)$, and the appearance of a decline phase after $35 \mathrm{~h}$ of growth, demonstrated differences between control and $20 \mathrm{mg} \mathrm{L}^{-1} \mathrm{Cd}$, which were confirmed by the Wilcoxon test $(p<0.01)$. As for $\mathrm{Zn}$ and $\mathrm{Cu}$, the cell concentration reached at the stationary phase was the same for control and for Cd-contaminated cultures.
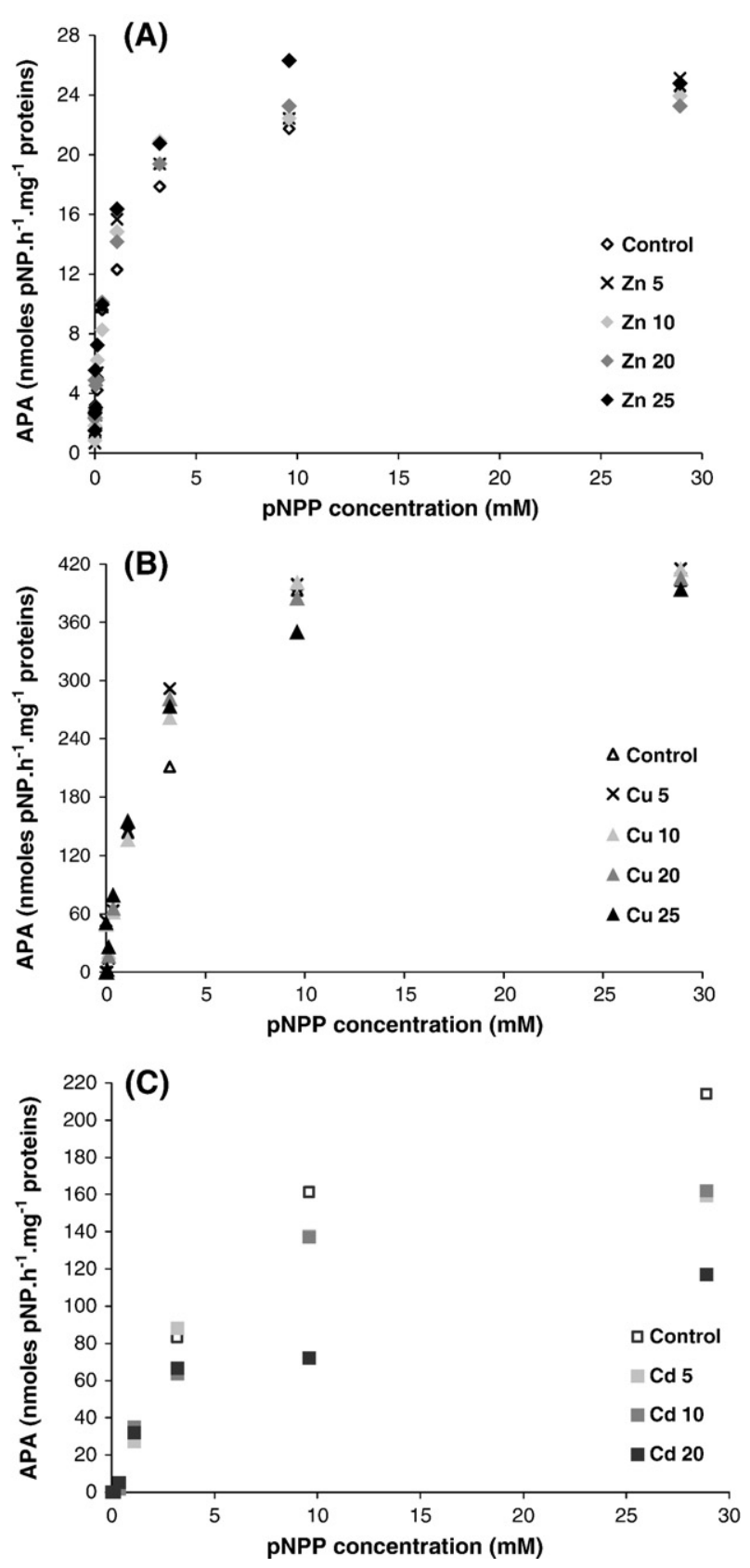

Fig. 2-Effects of $\mathrm{Zn}(\mathrm{A}), \mathrm{Cu}(\mathrm{B})$ and $\mathrm{Cd}(\mathrm{C})$ on alkaline phosphatase activities of Pseudomonas fluorescens BA3d12. 
Table 1 - Effects of heavy metals $\left(\mathrm{mg} \mathrm{L}^{-1}\right)$ on the APA Michaelis-Menten constants $\mathrm{V}_{\max }\left(\mathrm{nmol} \mathrm{pNP} \mathrm{h} \mathbf{h}^{-1} \mathrm{mg}^{-1}\right.$ proteins) and $\mathrm{K}_{\mathrm{m}}(\mathrm{mM})$

\begin{tabular}{lccc}
$\mathrm{V}_{\text {max }}$ & Zinc & Copper & Cadmium \\
\hline Control & 23.4 & 459.0 & 271.9 \\
$5 \mathrm{mg} \mathrm{L}^{-1}$ & 24.1 & 463.8 & 189.0 \\
$10 \mathrm{mg} \mathrm{L}^{-1}$ & 24.0 & 468.4 & 200.4 \\
$20 \mathrm{mg} \mathrm{L}^{-1}$ & 23.3 & 445.5 & 122.5 \\
$25 \mathrm{mg} \mathrm{L}^{-1}$ & 25.4 & 416.1 & - \\
& & & Cadmium \\
$\mathrm{K}_{\mathrm{m}}$ & Zinc & Copper & 7.27 \\
\hline Control $^{2}$ & 0.72 & 2.76 & 4.28 \\
$10 \mathrm{mg} \mathrm{L}^{-1}$ & 0.53 & 2.11 & 5.74 \\
$20 \mathrm{mg} \mathrm{L}^{-1}$ & 0.57 & 2.42 & 3.64 \\
$25 \mathrm{mg} \mathrm{L}^{-1}$ & 0.50 & 1.94 & - \\
\hline
\end{tabular}

For the three tested metals, the lowest concentration which has affected significantly the bacterial growth was $380 \mu \mathrm{M}$ for $\mathrm{Zn}\left(25 \mathrm{mg} \mathrm{L}^{-1}\right), 315 \mu \mathrm{M}$ for $\mathrm{Cu}\left(20 \mathrm{mg} \mathrm{L}^{-1}\right)$, and $90 \mu \mathrm{M}$ for $\mathrm{Cd}\left(10 \mathrm{mg} \mathrm{L}^{-1}\right)$. To conclude, the metal sensitivity of our Pseudomonas strain evaluated through its growth can be classified in the same order as for MICs, that is: $\mathrm{Cd}>\mathrm{Cu}>\mathrm{Zn}$.

\subsection{APA}

The influence of increasing $\mathrm{Zn}, \mathrm{Cu}$ and $\mathrm{Cd}$ concentrations on P. fluorescens phosphatase activity is shown in Fig. 2. Michaelis-Menten constants $\mathrm{V}_{\text {max }}$ and $\mathrm{K}_{\mathrm{m}}$ for the different used metal concentrations are included in Table 1. Note that the $\mathrm{V}_{\max }$ and $\mathrm{K}_{\mathrm{m}}$ values greatly differed between the three controls. Indeed, although all the concentrations of the same metal and its control were tested at the same time from the same enzyme extract, the three metals were studied separately, at different days, and from different extracts. Consequently, the $\mathrm{V}_{\max }$ and $\mathrm{K}_{\mathrm{m}}$ values of the control vary from one enzyme extract to another, and this variation can be generated either by the French Press (used to extract the enzyme), or by the storage of the strain at $+4{ }^{\circ} \mathrm{C}$ during several days between the various experiments (cf Material and methods section). Taking into account our experimental procedure, the influence of the metal concentration on the $\mathrm{V}_{\max }$ and $\mathrm{K}_{\mathrm{m}}$ values was studied metal by metal.

\subsubsection{Zinc}

Increasing $\mathrm{Zn}$ concentrations seemed to increase the P. fluorescens phosphatase activity, as shown by the $V_{\max }$ values globally higher for the Zn-contaminated sample than for the control. This positive influence of $\mathrm{Zn}$ was more pronounced at $25 \mathrm{mg} \mathrm{L}^{-1}(+9 \%)$, for which a higher $\mathrm{V}_{\max }$ value (25.4 nmol $\mathrm{pNP} \mathrm{h}^{-1} \mathrm{mg}^{-1}$ ) was recorded.

\subsubsection{Copper}

The influence of $\mathrm{Cu}$ was much less significant, with almost no difference between phosphatase activities of the 5, 10 and $20 \mathrm{mg} \mathrm{L}^{-1}$ contaminated medium and the control. However, at $25 \mathrm{mg} \mathrm{L}^{-1}$, Cu slightly inhibited the APA, as shown by the moderate decrease $(-10 \%)$ for the contaminated medium $\left(\mathrm{V}_{\max }=416.1 \mathrm{nmol} \mathrm{pNP}^{-1} \mathrm{mg}^{-1}\right)$ relative to the control $\left(\mathrm{V}_{\max }=459.0 \mathrm{nmol} \mathrm{pNP} \mathrm{h}{ }^{-1} \mathrm{mg}^{-1}\right)$.

\subsubsection{Cadmium}

For pNPP concentrations higher than $4 \mathrm{mM}$, the enzyme kinetics in the presence of Cd greatly differed from the control. Cd strongly inhibited the APA at all concentrations tested, as confirmed by the lower $\mathrm{V}_{\text {max }}$ when enzyme and substrate were exposed to the toxic metal. For example, the minimal $\mathrm{V}_{\text {max }}\left(122.5 \mathrm{nmol} \mathrm{pNP} \mathrm{h}^{-1} \mathrm{mg}^{-1}\right.$ ) observed at the highest Cd concentration (20 $\left.\mathrm{mg} \mathrm{L}^{-1}\right)$, represented only $45 \%$ of the control

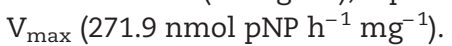

Finally, among the three metals tested, Cd induced the more drastic differences compared to the control. In contrast, whatever the metal tested, the phosphatase affinity for $\mathrm{pNPP}$, expressed as $\mathrm{K}_{\mathrm{m}}$ values, was always greater than for the control. Higher affinities (lower $K_{m}$ values) were recorded at the highest metal concentrations $(0.48 \mathrm{mM}$ pNPP for $25 \mathrm{mg} \mathrm{L}^{-1} \mathrm{Zn}, 1.73 \mathrm{mM}$ pNPP for $25 \mathrm{mg} \mathrm{L}^{-1} \mathrm{Cu}$ and $3.64 \mathrm{mM}$ pNPP for $20 \mathrm{mg} \mathrm{L}^{-1} \mathrm{Cd}$ ).

\section{4. $\mathrm{O}_{2}$ consumption}

The oxygen consumption rates for contaminated and control $P$. fluorescens cultures, are presented in Table 2. The table indicates also the percentages of metal activation $(+)$ or inhibition (-) on oxygen consumption.

\subsubsection{Zinc}

As observed for the enzyme activities, $\mathrm{Zn}$ was the only metal that activated $\mathrm{O}_{2}$ consumption by $P$. fluorescens. For any $\mathrm{Zn}$ concentration tested, $\mathrm{O}_{2}$ consumption rates were always higher than those of the control. These differences were statistically significant ( $T$ test: $p<0.05$ ). Compared to the control, the increase in $\mathrm{O}_{2}$ consumption (+30\%) was similar for 5,20 and $25 \mathrm{mg} \mathrm{L}^{-1} \mathrm{Zn}$, whereas it was maximal (+44\%) at $10 \mathrm{mg} \mathrm{L}^{-1} \mathrm{Zn}$.

Table 2 - Effects of heavy metals $\left(\mathrm{mg} \mathrm{L}^{-1}\right)$ on the oxygen consumption rates $\left(\mathrm{R}\right.$, in $\mu \mathrm{mol} \mathrm{O}_{2} \mathrm{~mL}^{-1} \mathrm{~min}^{-1}$ ) of Pseudomonas fluorescens BA3d12. Metal activation ( + ) or inhibition ( - ) on oxygen consumption is expressed by $P$, in $\%$

\begin{tabular}{|c|c|c|c|c|c|c|}
\hline \multirow[t]{2}{*}{ Metals } & \multicolumn{2}{|c|}{ Zinc } & \multicolumn{2}{|c|}{ Copper } & \multicolumn{2}{|c|}{ Cadmium } \\
\hline & $\mathrm{R}$ & $\mathrm{P}$ & $\mathrm{R}$ & $\mathrm{P}$ & $\mathrm{R}$ & $\mathrm{P}$ \\
\hline Control & $-0.479 \pm 0.039$ & - & $-0.841 \pm 0.027$ & - & $-0.684 \pm 0.077$ & - \\
\hline $5 \mathrm{mg} \mathrm{L}^{-1}$ & $-0.614 \pm 0.003$ & $+28 \%$ & $-0.791 \pm 0.005$ & $-6 \%$ & $-0.578 \pm 0.024$ & $-15 \%$ \\
\hline $10 \mathrm{mg} \mathrm{L}^{-1}$ & $-0.692 \pm 0.031$ & $+44 \%$ & $-0.636 \pm 0.041$ & $-24 \%$ & $-0.387 \pm 0.006$ & $-43 \%$ \\
\hline $20 \mathrm{mg} \mathrm{L}^{-1}$ & $-0.638 \pm 0.007$ & $+33 \%$ & $-0.461 \pm 0.025$ & $-45 \%$ & $-0.350 \pm 0.011$ & $-49 \%$ \\
\hline $25 \mathrm{mg} \mathrm{L}^{-1}$ & $-0.651 \pm 0.016$ & $+36 \%$ & - & - & - & - \\
\hline
\end{tabular}



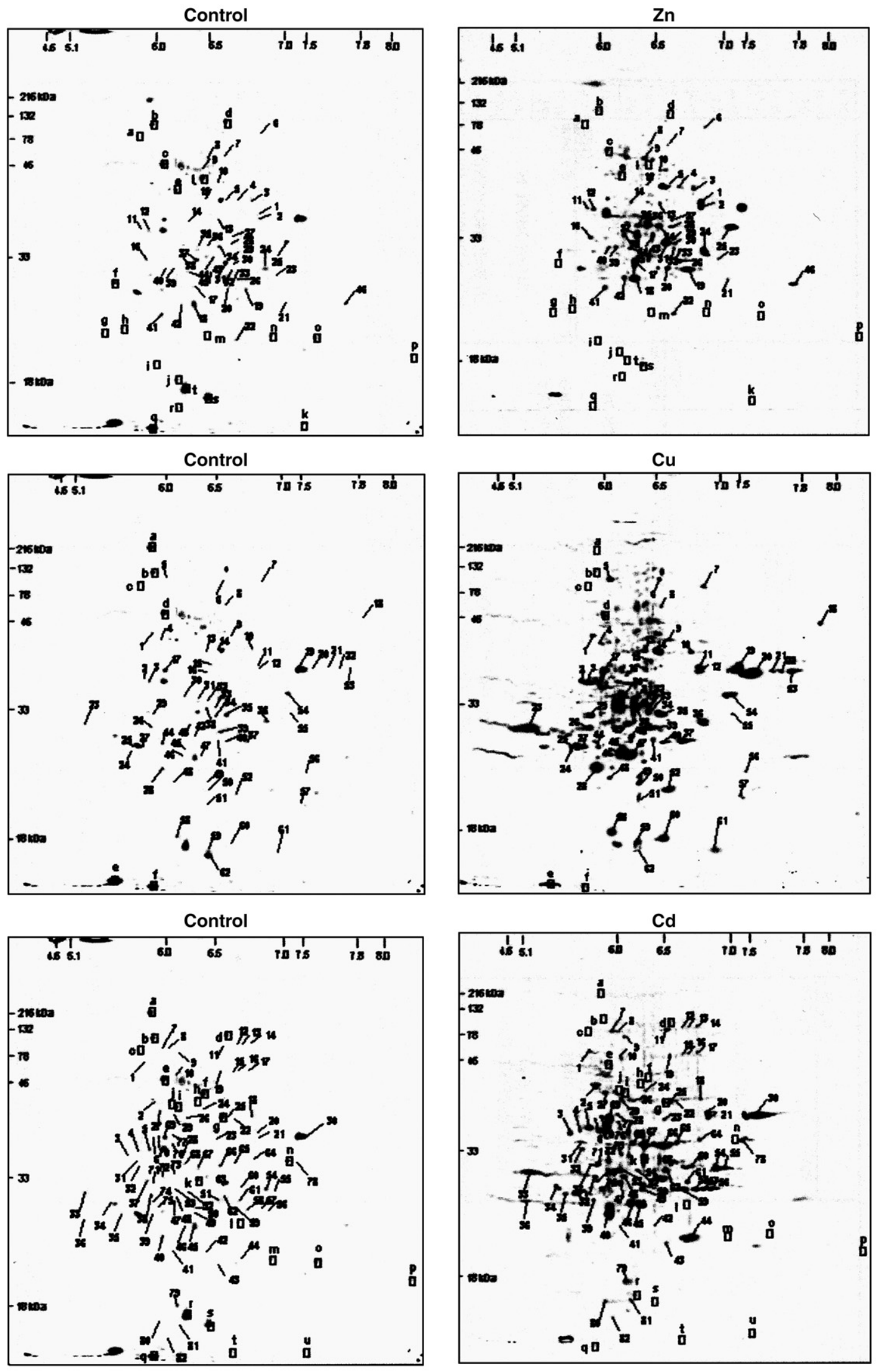

Fig. 3-2D-electrophoresis gels of Pseudomonas fluorescens BA3d12 proteome when grown without metal, in the presence of $20 \mathrm{mg} \mathrm{L}^{-1} \mathrm{Zn}, \mathrm{Cu}$ or $\mathrm{Cd}$. Proteins were stained with silver nitrate. Squares and lines indicate less and more intense spots, respectively, after metal treatments. 
Table 3-Differential protein spots visualized when Pseudomonas fluorescens BA3d12 was exposed to $20 \mathrm{mg} \mathrm{L}^{-1}$ of $\mathbf{Z n}, \mathbf{C u}$ or $\mathbf{C d}$

\begin{tabular}{lccc} 
Metal & $\begin{array}{c}\text { Overexpressed } \\
\text { or appeared } \\
\text { proteins }\end{array}$ & $\begin{array}{c}\text { Underexpressed } \\
\text { or disappeared } \\
\text { proteins }\end{array}$ & $\begin{array}{c}\text { Total } \\
\text { differential } \\
\text { expressed } \\
\text { proteins }\end{array}$ \\
\hline Zinc & 45 & 20 & 65 \\
Copper & 62 & 6 & 68 \\
Cadmium & 82 & 21 & 103 \\
\hline
\end{tabular}

\subsubsection{Copper}

The presence of $\mathrm{Cu}$ reduced $\mathrm{O}_{2}$ uptake rates, as shown by differences between the contaminated sample and control. Whereas at $5 \mathrm{mg} \mathrm{L}^{-1} \mathrm{Cu}, \mathrm{O}_{2}$ uptake differed little from the control (-0.791 and $-0.841 \mu \mathrm{mol} \mathrm{mL}^{-1} \mathrm{~min}^{-1}$, respectively), modifications were more significant ( $T$ test: $p<0.05$ ) at higher metal concentrations, particularly at $20 \mathrm{mg} \mathrm{L}^{-1} \mathrm{Cu}$. At this latter concentration, a clear reduction (-45\%) in $\mathrm{O}_{2}$ uptake rate was observed in comparison to the control.

\subsubsection{Cadmium}

The Cd-contaminated samples exhibited the greatest reduction in $\mathrm{O}_{2}$ consumption rate (Table 2). $\mathrm{O}_{2}$ consumption rates quickly decreased with increasing $\mathrm{Cd}$ contamination, ranging from $-0.578 \mu \mathrm{mol} \mathrm{mL} \mathrm{min}^{-1} \mathrm{~min}^{-1} \mathrm{mg} \mathrm{L}^{-1}$ to only $-0.350 \mu \mathrm{mol}$ $\mathrm{mL}^{-1} \mathrm{~min}^{-1}$ at $20 \mathrm{mg} \mathrm{L}^{-1}$. Compared with the control, this reduction in $\mathrm{O}_{2}$ consumption was first moderate at $5 \mathrm{mg} \mathrm{L}^{-1}$ $(-15 \%)$, to finally reach significant values ( $T$ test: $p<0.05)$ at 10 and $20 \mathrm{mg} \mathrm{L}^{-1}$ (respectively -43 and $-49 \%$ ).

Among the three tested metals, whereas $\mathrm{Cu}$ and $\mathrm{Cd}$ uniformly reduced $\mathrm{O}_{2}$ consumption, $\mathrm{Zn}$ always stimulated its consumption.

\subsection{Pseudomonas BA3d12 protein maps}

The proteins from control and contaminated bacteria, separated on 2D-gels, are shown in Fig. 3. Whatever the metal added, the protein maps differed greatly from that of the control; the number of spots exhibiting a difference in intensity was 65,68 , and 103 , for $\mathrm{Zn}, \mathrm{Cu}$ and $\mathrm{Cd}$, respectively (Table 3). Most of them appeared de novo or increased in intensity (Table 3).

\section{Discussion}

\subsection{MICs}

P. fluorescens BA3d12 has shown a high level of resistance to all the metals tested, since continued growth was observed in the presence of high metal concentrations. The MIC values indicated that this strain was sensitive to heavy metals in the following order: $\mathrm{Cd}>\mathrm{Cu}>\mathrm{Zn}$. A relatively diverse range of Pseudomonas MICs have been reported for $\mathrm{Cu}, \mathrm{Cd}$ or $\mathrm{Zn}$. For $\mathrm{Cu}$, Teitzel and Parsek (2003) found a MIC of $127 \mathrm{mg} \mathrm{L}^{-1}$ for Pseudomonas aeruginosa, and Chen et al. (2006) $190 \mathrm{mg} \mathrm{L}^{-1}$ for Pseudomonas putida, whereas Bender and Cooksey (1986) obtained a value of $6.35 \mathrm{mg} \mathrm{L}^{-1}$ for Pseudomonas syringae, and
Tom-Petersen et al. (2001) $3 \mathrm{mg} \mathrm{L}^{-1}$ for P. fluorescens. For Zn, MICs range between $50 \mathrm{mg} \mathrm{L}^{-1}$ for Pseudomonas sp. (Malik and Jaiswal, 2000) and $3139 \mathrm{mg} \mathrm{L}^{-1}$ for P. aeruginosa (De Vincente et al., 1990). For Cd, some Pseudomonas strains were incapable of growth at Cd concentrations above $1.1 \mathrm{mg} \mathrm{L}^{-1}$ (Zawadzka et al., 2007), whereas other strains could tolerate concentrations as high as $1000 \mathrm{mg} \mathrm{L}^{-1}$ (Pseudomonas sp.: Malik and Jaiswal, 2000; P. putida: Hu and Zhao, 2007). By comparing our results with those quoted previously, it appears that our Pseudomonas strain presents a high metal resistance.

Many publications have shown that MICs depend on the contamination of the study site from which strains have been isolated. In a general way, the absence of metal in the bacterial environment noticeably reduces its degree of resistance (Timoney et al., 1987; Ryan et al., 2005). By contrast, harbours are known to be metal-contaminated and for this reason accommodate resistant species (Ford et al., 2005). Previous studies have reported a metal contamination of St Anne's Bay (confidential data), which could explain the presence at this site of metal-tolerant Pseudomonas strains. According to Teitzel and Parsek (2003), MICs depend on the culture medium used. Generally, the highest values are obtained with a complex-rich growth medium, probably on account of the high complexation of the metal ions by growth medium components. Metal speciation is crucial to an understanding quantitative aspects of metal toxicity. Diffusion, complexation and availability of metals differ in solid culture media in comparison to liquid media. In our study, we have worked in liquid medium, since in these conditions, the free toxic metal ions evoke lower inhibitory concentrations than in solid medium where these ions are less available (Hassen et al., 1998a,b; Yilmaz, 2003). Moreover, liquid media better permit an evaluation of metal toxicity in polluted environments (Hassen et al., 1998a). As the MIC values depend on several parameters, it is difficult to compare data from different authors and experimental conditions.

\subsection{Effects of heavy metals on Pseudomonas BA3d12 growth kinetics}

Although many studies address the effects of metals on growth kinetics, it is difficult to make an accurate and meaningful comparison of our results with the literature, due to the very diverse growth media and incubation conditions. However, it is generally accepted that addition of metals in the culture medium implies modifications in Pseudomonas growth kinetics. The most frequently mentioned effects are: an increase in the lag phase (Cabrero et al., 1998; Teitzel and Parsek, 2003; Kassab and Roane, 2006; Chen et al., 2006), a decrease in the $\mu_{\max }$ (Appanna and Whitmore, 1995; Appanna and St Pierre, 1996; Cabrero et al., 1998; Yilmaz, 2003; Kassab and Roane, 2006; Tsai et al., 2006), mortality at the beginning of metal exposure (Kassab and Roane, 2006), decrease in biomass production (Appanna and Whitmore, 1995; Cabrero et al., 1998; Benka-Coker and Ekundayo, 1998; Tsai et al., 2006), stimulation of biomass production (Chen et al., 2006), or an early decline phase (Chen et al., 2006). In our study, a major increase in lag phase was observed for only high metal concentrations: $20 \mathrm{mg} \mathrm{L}^{-1} \mathrm{Cu}(315 \mu \mathrm{M})$ and $25 \mathrm{mg} \mathrm{L}^{-1} \mathrm{Zn}$ $(380 \mu \mathrm{M})$. During this longer lag phase, cells could acquire a 
metal resistant phenotype involving protein overproduction (Cooksey, 1993; Appanna et al., 1995; Hantke, 2001; Valls et al., 2000; Sharma et al., 2006; Kassab and Roane, 2006), or an increased exocellular metabolite production in order to complex metal ions and reduce bioavailability (Chan and Dean, 1988; Appanna and Whitmore, 1995; Appanna et al., 1995; Kassab and Roane, 2006). For BA3d12, no Cd concentration tested induced a longer lag phase. This observation suggests that this strain rapidly adapted to high $\mathrm{Cd}$ contamination (20 $\mathrm{mg} \mathrm{L}^{-1}$ or $180 \mu \mathrm{M}$ ). In the presence of this metal, the moderate increase in lag phase, the decrease in $\mu_{\max }$ and the early decline phase agreed well with the results obtained by Higham et al. (1986). These authors have shown that the resistance mechanisms of $P$. putida to $C d$, involved a complexation of this metal in polyphosphate granules, changes in the structure of cell membrane and the induction of three cysteine-rich low molecular weight proteins. For similar concentrations ( $20 \mathrm{mg} \mathrm{L}^{-1}=315 \mu \mathrm{M}$ for $\mathrm{Cu}$ and $305 \mu \mathrm{M}$ for $\mathrm{Zn}$ ), $\mathrm{Zn}$ had the least effect on growth kinetics, whereas $\mathrm{Cu}$ showed the strongest effect, which was in good agreement with several studies (Hassen et al., 1998a; Cabrero et al., 1998; Yilmaz, 2003; Chen et al., 2006). Indeed, $\mathrm{Zn}$ is an essential trace element and Pseudomonas is known to have many $\mathrm{Zn}$ homeostasis regulatory systems (Appanna et al., 1995; Hassan et al., 1999; Hantke, 2001). Cu is also essential but can be toxic at low concentrations (Wayne Outten et al., 2001). In this case, non-inducible systems (efflux, biosorption...) cannot be sufficient to control $\mathrm{Cu}$ homeostasis, resulting in a perturbed bacterial growth. As a result, it may become necessary for tolerant microorganisms to use inducible metal resistance mechanisms, including ATPdependent efflux pumps and intracellular sequestration (Cooksey, 1993; Saxena et al., 2002; Chen et al., 2006; Zhang and Rainey, 2007).

\subsection{Effects of heavy metals on APA}

A clear inhibition of APA occurred at low Cd concentrations (5 $\mathrm{mg} \mathrm{L}^{-1}$ ), whereas a moderate decrease in APA was observed only at a high $\mathrm{Cu}$ concentration $\left(25 \mathrm{mg} \mathrm{L}^{-1}\right)$. Many authors have reported an inhibition of phosphatase activities in the presence of heavy metals (Tyler, 1974; Roy et al., 2004). It is accepted that $\mathrm{Cd}$ and $\mathrm{Cu}$ are more toxic than other metals (Hiroki, 1992; Blum and Schwedt, 1998). Our APA results are in agreement with those of Chan and Dean (1988), who found that Cd inhibited APA of Pseudomonas marina at all tested concentrations, with an inhibitory effect proportional to the concentration tested. Similarly, Acosta-Martinez and Tabatabai (2001), who examined the effect of 25 trace elements on enzyme activities in soils, showed that Cd was one of the most effective inhibitors ( $>55 \%$ ), whereas $\mathrm{Cu}$ was a little less inhibitory (between 35 and 53\%). The activity of extracellular phosphatases will be affected by trace metals that induce changes in the three-dimensional enzyme conformation (Juma and Tabatabai, 1977; Geiger et al., 1998). These changes could be partly explained by metal sulfide formation at the cysteine residus (Roy et al., 2004). Other hypotheses to explain APA inhibition by $\mathrm{Cd}$ and $\mathrm{Cu}$, include metal interaction with the enzyme-substrate complex, or a metal complexation with the substrate alone (Eivazi and Tabatabai, 1990; Nannipieri, 1995). Alkaline phosphatase is a metalloenzyme composed of two monomers, requiring $\mathrm{Zn}$ and/or $\mathrm{Mg}$ to give the dimer responsible for enzymatic activity (Coleman, 1998). As a result, a possible mechanism to explain heavy metal toxicity on phosphatase activities could be the substitution of $\mathrm{Zn}$ by another element in the enzyme structure (Renella et al., 2003). Taking into account the chemical properties of $\mathrm{Zn}, \mathrm{Cu}$ and $\mathrm{Cd}$, $\mathrm{Cd}$ - better than $\mathrm{Cu}$ - could substitute $\mathrm{Zn}$ within the enzyme. Other studies have mentioned inhibition of APA by Zn beyond a certain threshold concentration (Gary and Santiago, 1977; Mazorra et al., 2002). Indeed, the excess of $\mathrm{Zn}$ would replace $\mathrm{Mg}$ at the $\mathrm{Mg}$-binding sites in the AP, thus inducing inhibition of APA (Yan and Chen, 1986; Lan et al., 1995).

Metals can inhibit the APA, but they do stimulate it, too. Indeed, in the presence of metal, high enzyme affinities for the substrate (expressed as low $\mathrm{K}_{\mathrm{m}}$ values) were recorded in our study, which suggests some efficient interactions between the enzyme and its substrate, due to the metal. We also observed a positive influence of $\mathrm{Zn}$ on APA, through the $\mathrm{V}_{\max }$ values. Similar observations have been reported by Wong et al. (1995), who found a positive correlation between APA and total $\mathrm{Zn}$ content in the marine sediments of a polluted Hong-Kong harbour. Lan et al. (1995) have also demonstrated that APA was significantly increased by $0.1 \mathrm{mg} \mathrm{L}^{-1} \mathrm{Zn}$ in the red sea bream Chrysophrys major. As described by Blum and Schwedt (1998), other analogous enzyme activities can be activated by this metal, such as that of phosphodiesterase I. Similarly, several studies have shown that the loss of enzymatic activity could be restored by addition of $\mathrm{Zn}$ (Olsen et al., 1991; Blum and Schwedt, 1998). The best explanation for the stimulation by this element is probably that the phosphatase (a Zn-enzyme) works optimally when it has enough $\mathrm{Zn}$ (Blasco et al., 1993). Finally, the optimal APA seems to be ensured by an optimal - but not excessive - Zn concentration.

\subsection{Effects of heavy metals on $\mathrm{O}_{2}$ consumption}

In the present study, $\mathrm{O}_{2}$ consumption by P. fluorescens was clearly decreased in the presence of $\mathrm{Cd}$. In most cases, inhibition of respiration by toxic metals is expected, with a gradual decrease in $\mathrm{O}_{2}$ consumption in response to an increase in metal concentration. In their study on the effects of Cd on respiration, Chan and Dean (1988) also found that $\mathrm{O}_{2}$ uptake by the marine bacterium P. marina was inhibited at all Cd concentrations. According to Smith and Giller (1992), Cd is expected to cause the most adverse effects on the biomass activity, which agrees well with our results. Inhibition of respiration by $\mathrm{Cd}$ is attributed to the $\mathrm{Cd}$ transport into the bacterial cells via the energy-dependent $\mathrm{Mn}^{2+}$ transport system, and additionally, to the binding of $\mathrm{Cd}$ ions to the SH groups of the respiratory enzymes (Perry and Silver, 1982).

Our results also indicated an inhibition of oxygen consumption by $\mathrm{Cu}$ at high concentrations $\left(20 \mathrm{mg} \mathrm{L}^{-1}\right.$ or $\left.315 \mu \mathrm{M}\right)$. The toxic influence of this metal on bacterial metabolism is often reported, as shown by Tsai and Tuovinen (1985) who obtained an almost complete repression of $\mathrm{O}_{2}$ uptake by $\mathrm{Ni}$ trobacter spp. in the presence of $17 \mathrm{mM} \mathrm{Cu}$. In our study, Cu inhibition seemed less severe than that observed for $\mathrm{Cd}$, whereas Codina et al. (1994) showed a similar effect of Cu or Cd on P. fluorescens. Riis et al. (2002) reported a higher toxicity of $\mathrm{Cu}$ compared to $\mathrm{Cd}$ on a soil bacterium population, and Renella 
et al. (2002) reported a variable relative toxicity of the two elements on a soil microbial biomass taking into account the metal incubation time. Taken together, these results underline once more that comparisons between data are difficult as parameters are rarely comparable from one study to another.

In the present study, the results on $\mathrm{O}_{2}$ uptake obtained with bacteria contaminated with $\mathrm{Zn}$ are surprisingly quite different from those described in the presence of $\mathrm{Cd}$ and $\mathrm{Cu}$. Whatever the concentration added in the medium, $\mathrm{Zn}$ always activated $\mathrm{O}_{2}$ uptake, by up to $44 \%$. Although Wong et al. (1997) and Rajapaksha et al. (2004) found an inhibition of respiration in the presence of $\mathrm{Zn}$, our results are in agreement with other studies. Indeed, Brookes and McGrath (1984) report a specific respiration rate in contaminated soils two-fold higher that in uncontaminated soils. Similarly, Khan and Scullion (2000, 2002) have shown that the $\mathrm{Zn}$ addition to sewage sludges increased microbial respiration rates. Respiration responses to metal inputs are determined by a balance of reductions in microbial biomass and stress-induced increases in metabolic quotients (Fließbach et al., 1994). In our experiments, we have always measured $\mathrm{O}_{2}$ consumption in samples with the same bacterial densities. As a result, differences in biomass cannot explain the activation of respiration by $\mathrm{Zn}$, nor its inhibition by $\mathrm{Cu}$ and $\mathrm{Cd}$. For $\mathrm{Zn}$, our results suggest rather that the metabolic responses to stress are important, making $\mathrm{Zn}$ less toxic than $\mathrm{Cu}$ and $\mathrm{Cd}$. This is in agreement with the study of Khan and Scullion (2000). By virtue of its strong Lewis acid properties, zinc can polarize, coordinate and activate substrates, which enables this heavy metal to participate in various regulatory processes (Appanna and Whitmore, 1995). It is a component or activator of some enzymes; it is a stabilizer of macromolecules and biological membranes (Chvapil, 1973) and it maintains the integrity of the cell wall of gram-negative bacteria (Eagon et al., 1965). Zinc could also stimulate the activity of constitutive enzymes, as for example, the oxygen-dependent glucose dehydrogenase (EC 1.1.99.17) whose activity is enhanced by $5 \mathrm{mM} \mathrm{Zn}$ in Erwinia sp. (Marcinkeviciene et al., 1999). As this enzyme is also present in P. fluorescens (Matsushita and Ameyama, 1982), it is possible that such a stimulation exists also for this species. Another enzyme capable of being activated by an excess of Zn may be the $\mathrm{Zn}$ enzyme carbonic anhydrase (EC 4.2.1.1). This enzyme is known to catalyse transformation of $\mathrm{CO}_{2}$ produced by bacterial metabolism to $\mathrm{HCO}_{3}^{-}$anions (Pelmont, 1988). The P. fluorescens $\mathrm{O}_{2}$ uptake activation by $\mathrm{Zn}$ could result in a carbonic anhydrase stimulation or increased synthesis. Various studies have shown that elevated $\mathrm{Zn}$ concentrations induce siderophore biosynthesis in Pseudomonas (P. fluorescens: Rossbach et al., 2000; P. aeruginosa: Hoefte et al., 1994). Pyoverdine, the main siderophore synthesized by P. fluorescens, is an iron-scavenging molecule facilitating $\mathrm{Fe}^{3+}$ uptake into bacterial cells (Linget et al., 1992). As a result, this pyoverdine overproduction could induce higher iron concentrations in the intracellular compartment, resulting in a possible stimulation of enzymes involved in the bacterial respiratory chain, such as cytochrome oxidases.

\subsection{Effects of heavy metals on Pseudomonas BA3d12 protein map}

After silver staining of our gels, we have visualized 65 differential protein spots for $\mathrm{Zn}, 68$ for $\mathrm{Cu}$, and 103 for $\mathrm{Cd}$. Sharma et al. (2006) is the sole previous report of the impact of metals on P. fluorescens using proteomics; and among the metals tested by these authors, $\mathrm{Cu}$ is the only element in common with our study. For this metal, no more than 18 differentially expressed protein spots appeared, but the authors have used the Coomassie Brilliant Blue staining which is known to be less sensitive than the silver staining (Switzer et al., 1979). Our results, and those of Sharma et al. (2006), indicate that $P$. fluorescens responds to the stress due to metal contamination, by metabolic changes. Our results demonstrate that the main Pseudomonas response to metal contamination is the synthesis of new proteins and/or the increased synthesis of constitutive proteins (Table 3). These proteins could allow the bacteria to cope with metal stress through diverse strategies, such as biotransformation, active efflux, intra- or extracellular sequestration and metal transport (Appanna and Whitmore, 1995; Appanna et al., 1996; Saxena et al., 2002; Chen et al., 2006; Zhang and Rainey, 2007). Our results are in agreement with those of Hassen et al. (1998b) who observed that $\mathrm{Zn}$ stimulated protein synthesis by $P$. aeruginosa, this bacterium producing an amount of proteins two-fold higher than the control. In our case, when P. fluorescens was exposed to $20 \mathrm{mg} \mathrm{L}^{-1} \mathrm{Zn}$, we observed several more intense spots in the map area at approximately $30 \mathrm{kDa}$ and pI 6 (spots 16, 39 and 40 Fig. 4). Among them, carbonic anhydrase (MW $29 \mathrm{kDa}$ and pI 6) is a possible candidate for over-expression. As explained previously, the $\mathrm{O}_{2}$ uptake activation observed after $P$. fluorescens exposure to $\mathrm{Zn}$, could
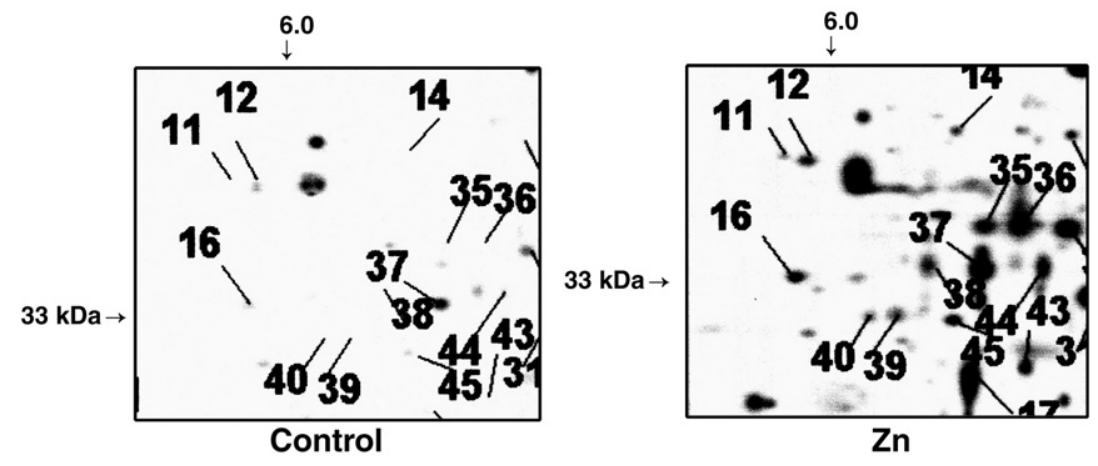

Fig. 4-Zooms of protein maps of Pseudomonas fluorescens BA3d12 for control and $20 \mathrm{mg} \mathrm{L}^{-1} \mathrm{Zn}$, at approximately $30 \mathrm{kDa}$ and pI 6. 
be followed by the carbonic anhydrase over-synthesis in order to eliminate the excessive $\mathrm{CO}_{2}$ production resulting from the respiratory activity. To confirm this hypothesis, the protein spots 16, 39 and 40 should be identified by mass spectrometry. In contrast, although $\mathrm{Zn}$ has activated APA, no spot at approximately $40 \mathrm{kDa}$ and pI 4.5 , which characterises the alkaline phosphatase (Plisova et al., 2005; Yamada and Tanoue, 2006), was observed. This suggests that this membrane enzyme may have been eliminated during preparation of the hydrosoluble protein extract, no protein spot corresponding to alkaline phosphatase being detected on the control 2D-gel. A stimulation of protein synthesis by heavy metals has already been observed by some authors. For instance, in response to oxidative stress induced in the presence of $\mathrm{Cu}$, Sharma et al. (2006) reported an increased level of the enzyme enolase. Cd is known to lead to newly synthetized proteins, called pseudothioneins and described previously (Higham et al., 1986). Finally, the results concerning the differential protein spots were in accordance with growth kinetics in the presence of metals. Indeed, we have observed only few modifications in growth kinetics with $20 \mathrm{mg} \mathrm{L}^{-1} \mathrm{Zn}$, which is also the metal that induced the lowest number of differential protein spots. In contrast, with $20 \mathrm{mg} \mathrm{L}^{-1} \mathrm{Cd}$ or $\mathrm{Cu}$, the strong modifications during bacterial growth could be linked with the important changes in the protein maps. This observation suggests that the protein over-synthetis probably occurred at the cost of the bacterial growth.

\section{Conclusions}

This study showed that P. fluorescens BA3d12, isolated from the strand zone of the St Anne Bay, is tolerant to high levels of metals, confirming that its site of origin is relatively polluted. Although living in a hostile environment, when this strain is cultivated in the laboratory, it is able to develop adaptation strategies to protect against heavy metal toxicity. The resistance that we observed is probably associated with newly synthesized stress-linked proteins or with elevated synthesis of constitutive proteins. In further studies, we will aim to identify by mass spectrometry analysis some of the differentially expressed proteins induced when the strain P. fluorescens BA3d12 is exposed to heavy metals.

\section{Acknowledgments}

The authors warmly thank Dr Richard Thompson for his corrections concerning the English language. This work was financially supported by the Syndicat mixte du Cotentin, the Conseil Régional de Basse-Normandie and the Direction de la Recherche du Ministère de l'Education Nationale, de l'Enseignement Supérieur et de la Recherche.

\section{R E F E R E N C E S}

Acosta-Martinez V, Tabatabai MA. Arylamidase activity in soils: effect of trace elements and relationships to soil properties and activities of amidohydrolases. Soil Biol Biochem 2001;33:17-23.
Appanna VD, Whitmore L. Biotransformation of zinc by Pseudomonas fluorescens. Microbios 1995;82:149-55.

Appanna VD, Finn H, St Pierre M. Exocellular phosphatidylethanolamine production and multiple-metal tolerance in Pseudomonas fluorescens. FEMS Microbiol Lett 1995;131:53-6.

Appanna VD, St Pierre M. Cellular response to a multiple-metal stress in Pseudomonas fluorescens. J Biotechnol 1996;48:129-36.

Azam F, Malfatti F. Microbial structuring of marine ecosystems. Nat Rev Microbiol 2007;5:782-91.

Bamforth SM, Singleton I. Bioremediation of polycyclic aromatic hydrocarbons: current knowledge and future directions. J Chem Technol Biotechnol 2005;80:723-36.

Bender CL, Cooksey DA. Indigenous plasmids in Pseudomonas syringae pv. tomato: conjugative transfer and role in copper resistance. J Bacteriol 1986;165:534-41.

Benka-Coker MO, Ekundayo JA. Effects of heavy metals on growth of species of Micrococcus and Pseudomonas in a crude oil/mineral salts medium. Bioresour Technol 1998;66:241-5.

Blasco J, Puppo J, Sarasquete MC. Acid and alkaline phosphatase activities in the clam Ruditapes philippinarum. Mar Biol 1993;115:113-8.

Blum U, Schwedt G. Inhibition behavior of acid phosphatase, phosphodiesterase I and adenosine deaminase as tools for trace metal analysis and speciation. Anal Chim Acta 1998;360:101-8.

Boge G, Bussiere D, Peres G. Effects of hexavalent chromium on enzymatic activities and transport process on intestinal brush border membrane of rainbow trout (Salmo gairdneri). Water Res 1988;22:441-7.

Bradford MM. A rapid and sensitive method for the quantification of microgram quantities of protein utilizing the principle of protein-dye binding. Anal Biochem 1976;72:248-54.

Brookes PC, McGrath SP. Effects of metal toxicity on the soil microbial biomass. J Soil Sci 1984;35:341-6.

Cabrero A, Fernandez S, Mirada F, Garcia J. Effects of copper and zinc on the activated sludge bacteria growth kinetics. Wat Res 1998;32:1355-62.

Castro-González M, Braker G, Farías L, Ulloa O. Communities of nirs-type denitrifiers in the water column of the oxygen minimum zone in the eastern South Pacific. Environ Microbiol 2005;7:1298-306.

Chan KY, Dean ACR. Effects of cadmium and lead on growth, respiration and enzyme activity of the marine bacterium Pseudomonas marina. Chemosphere 1988;17:597-607.

Chen XC, Shi JY, Chen YX, Xu XH, Xu SY, Wang YP. Tolerance and biosorption of copper and zinc by Pseudomonas putida CZ1 isolated from metal-polluted soil. Can J Microbiol 2006;52:308-16.

Chvapil M. New aspects in the biological role of zinc: a stabilizer of macromolecules and biological membranes. Life Sci 1973;13:1041-9.

Ciesielski S, Cydzik-Kwiatkowska A, Pokoj T, Klimiuk E. Molecular detection and diversity of medium-chain-length polyhydroxyalkanoates-producing bacteria enriched from activated sludge. J Appl Microbiol 2006;101:190-9.

Clark LC. Monitor and control of blood and tissue organ tensions. T Am Soc Art Int Org 1956;2:41-8.

Codina JC, Pérez-Garcia A, de Vicente A. Detection of heavy metal toxicity and genotoxicity in waste waters by microbial assay. Water Sci Technol 1994;30:145-51.

Coleman JE. Zinc enzymes. Curr Opin Chem Biol 1998;2:222-34.

Cooksey DA. Copper uptake and resistance in bacteria. Mol Microbiol 1993;7:1-5.

De Vincente AM, Aviles JC, Codina JC, Borrego JJ, Romero P. Resistance to antibiotics and heavy metals of Pseudomonas aeruginosa isolated from natural waters. J Appl Bacteriol 1990;68:625-32.

Eagon RG, Simmons GP, Carson KJ. Evidence for the presence of ash and divalent metals in the cell wall of Pseudomonas aeruginosa. Can J Microbiol 1965;11:1041-3. 
Eivazi F, Tabatabai MA. Factors affecting glucosidase and galactosidase activities in soils. Soil Biol Biochem 1990;22:891-7.

Fließbach A, Martens R, Reber HH. Soil microbial biomass and microbial activity in soil treated with heavy metal contaminated sewage sludge. Soil Biol Biochem 1994;26:1201-5.

Ford T, Jay J, Patel A, Kile M, Prommasith P, Galloway T, et al. Use of ecotoxicological tools to evaluate the health of New Bedford harbor sediments: a microbial biomarker approach. Environ Health Perspect 2005;113:186-91.

Gary GM, Santiago NA. Intestinal surface amino-oligopeptidases. I. Isolation of two weight isomers and their subunits from rat brush border. J Biol Chem 1977;252:4922-8.

Geiger G, Brandl H, Furrer G, Schulin R. The effect of copper on the activity of cellulase and glucosidase in the presence of montmorillonite or Al-montmorillonite. Soil Biol Biochem 1998;30:1537-44.

Hantke K. Bacterial zinc transporters and regulators. Biometals 2001;14:239-49.

Hassan MT, van der Lelie D, Springael D, Römling U, Ahmed N, Mergeay M. Identification of a gene cluster, czr, involved in cadmium and zinc resistance in Pseudomonas aeruginosa. Gene 1999;238:417-25.

Hassen A, Saidi N, Cherif M, Baudabous A. Resistance of environmental bacteria to heavy metals. Bioresour Technol 1998a;64:7-15.

Hassen A, Saidi N, Cherif M, Baudabous A. Effects of heavy metals on Pseudomonas aeruginosa and Bacillus thuringiensis. Bioresour Technol 1998b;65:73-82.

Higham DP, Sadler PJ, Scawen MD. Cadmium-binding proteins in Pseudomonas putida: pseudothioneins. Environ Health Persp 1986;65:5-11.

Hiroki M. Effects of heavy metal contamination on soil microbial population. Soil Sci Plant Nutr 1992;38:93-100.

Hoefte M, Dong Q Kourambas S, Krishnapillai V, Sherrat D, Mergeay $\mathrm{M}$. The sss gene product, which affects pyoverdin production in Pseudomonas aeruginosa 7NSK2, is a site-specific recombinase. Mol Microbiol 1994;14:1011-20.

$\mathrm{Hu} N$, Zhao B. Key genes involved in heavy-metal resistance in Pseudomonas putida CD2. FEMS Microbiol Lett 2007;267:17-22.

Jean N, Boge G, Jamet JL, Richard S, Jamet D. Seasonal changes in zooplanctonic alkaline phosphatase activity in Toulon Bay (France): the role of Cypris larvae. Mar Poll Bull 2003;46:346-52.

Juma NG, Tabatabai MA. Effects of trace elements on phosphatase activity in soils. Soil Sci Soc Am J 1977;41:343-6.

Kassab DM, Roane TM. Differential responses of a mine tailings Pseudomonas isolate to cadmium and lead exposures. Biodegradation 2006;17:379-87.

Khan M, Scullion J. Microbial responses to $\mathrm{Cu}, \mathrm{Ni}$ and $\mathrm{Zn}$ in metal enriched sewage sludge treated soil. Pakistan J Biol Sci 2000;3:1684-7.

Khan M, Scullion J. Effects of metal (Cd, Cu, Ni, Pb or Zn) enrichment of sewage-sludge on soil micro-organisms and their activities. Appl Soil Ecol 2002;20:145-55.

King EF, Painter HA. Inhibition of respiration of activated sludge: variability and reproducibility of results. Toxicity Ass 1986;1:27-39.

Laemmli UK. Cleavage of structural proteins during the assembly of the head of bacteriophage T4. Nature 1970;15:680-5.

Lan WG, Wong MK, Chen N, Sin YM. Effect of combined copper, zinc, chromium and selenium by orthogonal array design on alkaline phosphatase activity in liver of the red sea bream Chrysophrys major. Aquaculture 1995;131:219-30.

Linget C, Azadi P, MacLeod JK, Dell A, Abdallah MA. Bacterial siderophores: the structure of the pyoverdins of Pseudomonas fluorescens ATCC 13525. Tetrahedron 1992;33:1737-40.

Macaskie LE, Empson RM, Cheethman AK, Grey CP, Skarnulis AJ. Uranium bioaccumulation by a Citrobacter sp. as a result of enzymically mediated growth of polycristalline $\mathrm{HUO}_{2} \mathrm{PO}_{4}$. Science 1992;257:782-4.

Malik A, Jaiswal R. Metal resistance in Pseudomonas strains isolated from soil treated with industrial wastewater. World J Microb Biot 2000;16:177-82.

Marcinkeviciene L, Bachmatova I, Semenaite R, Rudomanskis R, Brazenas G, Meskiene R, et al. Purification and characterisation of PSS-dependent glucose dehydrogenase from Erwinia sp. 34-1. Biotechnol Lett 1999;21:187-92.

Matsushita K, Ameyama M. D-glucose dehydrogenase from Pseudomonas fluorescens, membrane-bound. Meth Enzymol 1982;89:149-54.

Mazorra MT, Rubio JA, Blasco J. Acid and alkaline phosphatase activities in the clam Scrobicularia plana: kinetic characteristics and effects of heavy metals. Comp Biochem Phys B 2002;131:241-9.

Mergeay M, Monchy S, Vallaeys T, Auquier V, Benotmane A, Bertin $\mathrm{P}$, et al. Ralstonia metallidurans, a bacterium specifically adapted to toxic metals: towards a catalogue of metal-responsive genes. FEMS Microbiol Rev 2003;27:385-410.

Nannipieri P. The potential use of soil enzymes as indicators of productivity, sustainability and pollution. In: Pankhurst CE, Doube BM, Gupta VVSR, Grace PR, editors. Soil Biota: management in sustainable farming systems. East Melbourne, Vic: CSIRO Publishing; 1995. p. 238-44.

Navarro L, Torres-Marquez ME, Gonzalez-Moreno S, Devars S, Hernandez R, Moreno-Sanchez R. Comparison of physiological changes in Euglena gracilis during exposure to heavy metals of heterotrophic and autotrophic cells. Comp Biochem Physiol 1997;116:265-72.

Newman DJ, Cragg GM. Advanced preclinical and clinical trials of natural products and related compounds from marine sources. Curr Med Chem 2004;11:1693-713.

Olsen RL, Overbo K, Myrnes B. Alkaline phosphatase from the hepatopancreas of shrimp (Pandalus borealis): a dimeric enzyme with catalytically active subunits. Comp Biochem Phys B 1991;99:755-61.

Pelmont J. In: Bornarel J, editor. Enzymes. Grenoble: Presses Universitaires de Grenoble; 1988. 70 pp.

Perry RD, Silver S. Cadmium and manganese transport in Staphylococcus aureus membrane vesicles. J Bacteriol 1982;150:973-6.

Plisova EY, Balabanova LA, Ivanova EP, Kozhemyako VB, Mikhailov VV, Agafonova EV, et al. A highly active alkaline phosphatase from the marine bacterium Cobetia. Mar Biotechnol 2005;7:173-8.

Rajapaksha RMCP, Tobor-Kaplon MA, Baath E. Metal toxicity affects fungal and bacterial activities in soil differently. Appl Environ Microb 2004;70:2966-73.

Renella G, Chaudri AM, Brookes PC. Fresh additions of heavy metals do not model long-term effects on microbial biomass and activity. Soil Biol Biochem 2002;34:121-4.

Renella G, Ortigoza ALR, Landi L, Nannipieri P. Additive effects of copper and zinc on cadmium toxicity on phosphatase activities and ATP content of soil as estimated by the ecological dose (ED 50$)$. Soil Biol Biochem 2003;35:1203-10.

Riis V, Babel W, Pucci OH. Influence of heavy metals on the microbial degradation on diesel fuel. Chemosphere 2002;49:559-68.

Ron EZ, Minz D, Finkelstein NP, Rosenberg E. Interactions of bacteria with cadmium. Biodegradation 1992;3:161-70.

Rossbach S, Wilson TL, Kukuk ML, Carty HA. Elevated zinc unduces siderophore biosynthesis genes and a zntA-like gene in Pseudomonas fluorescens. FEMS Microbiol Lett 2000;191:61-70.

Roy S, Bhattacharyya P, Ghosh AK. Influence of toxic metals on activity of acid and alkaline phosphatase enzymes in metal-contaminated landfill soils. Aust J Soil Res 2004;42:339-44. 
Ryan RP, Ryan DJ, Dowling DN. Multiple metal resistant transferable phenotypes in bacteria as indicators of soil contamination with heavy metals. J. Soil Sediments 2005;5:95-100.

Saxena D, Joshi N, Srivastava S. Mechanism of copper resistance in a copper mine isolate Pseudomonas putida strain S4. Curr Microbiol 2002;45:410-4.

Sharma S, Sundaram CS, Luthra PM, Singh Y, Sirdeshmukh R, Gade WN. Role of proteins in resistance mechanism of Pseudomonas fluorescens against heavy metal induced stress with proteomics approach. J Biotechnol 2006;126:374-82.

Siddiqui IA, Haas D, Heeb S. Extracellular protease of Pseudomonas fluorescens $\mathrm{CHAO}$, a biocontrol factor with activity against the root-knot nematode Meloidogyne incognita. Appl Environ Microbiol 2005;71:5646-9.

Silby MW, Levy SB. Use of in vivo expression technology to identify genes important in growth and survival of Pseudomonas fluorescens PfO-1 in soil: discovery of expressed sequences with novel genetic organization. J Bacteriol 2004;186:7411-9.

Silver S. Bacterial silver resistance: molecular biology and uses and misuses of silver compounds. FEMS Microbiol Rev 2003;27:341-53.

Smith SR, Giller KE. Effective Rhizobium leguminosarum present in five soils contaminated with heavy metals from long-term applications of sewage sludge or metal mine spoil. Soil Biol Biochem 1992;24:781-8.

Stockwell VO, Loper JE. The sigma factor RpoS is required for stress tolerance and environmental fitness of Pseudomonas fluorescens Pf-5. Microbiology 2005;151:3001-9.

Switzer R, Merrill C, Shifrin S. A highly sensitive silver stain for detecting proteins and peptides in polyacrylamide gels. Anal Biochem 1979;98:231-7.

Takenaka S, Tonoki T, Taira K, Murakami S, Aoki K. Adaptation of Pseudomonas sp. strain 7-6 to quaternary ammonium compounds and their degradation via dual pathways. Appl Environ Microbiol 2007;73:1797-802.

Teitzel GM, Parsek MR. Heavy metal resistance of biofilm and planktonic Pseudomonas aeruginosa. Appl Environ Microbiol 2003;69:2313-20.

Timoney JF, Port J, Giles J, Spanier J. Heavy-metal and antibiotic resistance in the bacterial flora of sediments of New York Bight. Appl Environ Microbiol 1987;36:465-72.

Tom-Petersen A, Hosbond C, Nybroe O. Identification of copper-induced genes in Pseudomonas fluorescens and use of a reporter strain to monitor bioavailable copper in soil. FEMS Microbiol Ecol 2001;38:59-67.

Tsai YL, Tuovinen OH. Oxygen uptake activity by Nitrobacter spp. in the presence of metal ions and sulfoxyanions. FEMS Microbiol Lett 1985;28:11-4.
Tsai YP, You SJ, Pai TY, Chen KW. Effect of Cd(II) on different bacterial species present in a single sludge activated sludge process for carbon and nutrient removal. J Environ Eng 2006;132:173-80.

Tyler G. Heavy metal pollution and soil enzymatic activity. Plant Soil 1974;41:303-11.

Valls M, de Lorenzo V, Gonzalez-Duarte R, Atrian S. Engineering outer-membrane proteins in Pseudomonas putida for enhanced heavy-metal bioadsorption. J Inorg Biochem 2000;79:219-23.

Vasudevan N, Bharathi S, Arulazhagan P. Role of plasmid in the degradation of petroleum hydrocarbon by Pseudomonas fluorescens NS1. J Environ Sci Heal A 2007;42:1141-6.

Vilain S, Cosette P, Zimmerlin I, Dupont JP, Junter GA, Jouenne T. Biofilm proteome: homogeneity or versatility? J Prot Res 2004;3:132-6.

Wayne Outten F, Huffman DL, Hale JA, O'Halloran TV. The independent cue and cus systems confer copper tolerance during aerobic and anaerobic growth in Escherichia coli. J Biol Chem 2001;276:30670-7.

Wong YS, Tam NFY, Lau PS, Xue XZ. The toxicity of marine sediments in Victoria harbour, Hong-Kong. Mar Poll Bull 1995;31:464-70.

Wong KY, Zhang MQ Li XM, Lo W. A luminescence-based scanning respirometer for heavy metal toxicity monitoring. Biosens Bioelectron 1997;12:125-33.

Yamada N, Tanoue E. The inventory and chemical characterization of dissolved proteins in oceanic waters. Prog Oceanogr 2006;69:1-18.

Yan S, Chen Q. Effect of metal ions on the Amphioxus alkaline phosphatase. J Xiamen Univ (Nat Sci) 1986;25:692-8.

Yilmaz EI. Metal tolerance and biosorption capacity of Bacillus circulans strain EB1. Res Microbiol 2003;154:409-15.

Zhang XX, Rainey PB. The role of a P1-type ATPase from Pseudomonas fluorescens SBW25 in copper homeostasis and plant colonization. Mol Plant Microbe In 2007;20:581-8.

Zawadzka AM, Crawford RL, Paszczynski AJ. Pyridine-2,6-bis (thiocarboxylic acid) produced by Pseudomonas stutzeri KC reduces chromium(VI) and precipitates mercury, cadmium, lead and arsenic. Biometals 2007;20:145-58.

Zhou F, Guo H, Liu L. Quantitative identification and source apportionment of anthropogenic heavy metals in marine sediment of Hong Kong. Environ Geol 2007a;53:295-305.

Zhou F, Guo H, Hao Z. Spatial distribution of heavy metals in Hong Kong's marine sediments and their human impacts: a GIS-based chemometric approach. Mar Pollut Bull 2007b;54:1372-84. 